\title{
Erratum to: Assessment of a combination screening assay for celiac disease
}

\author{
Brunetta Porcelli · Fabio Ferretti · Carla Vindigni · \\ Carlo Scapellato $\cdot$ Lucia Terzuoli
}

Published online: 11 October 2011

(c) Springer-Verlag 2011

\section{Erratum to: Autoimmun Highlights}

\section{DOI 10.1007/s13317-011-0020-1}

In the original published article, the family name of the fourth author was misspelled. The correct name is Carlo Scapellato.

The online version of the original article can be found under doi:10.1007/s13317-011-0020-1.

B. Porcelli $(\bowtie) \cdot$ L. Terzuoli

University of Siena, Polo Scientifico di San Miniato

Via Alcide Dè Gasperi 2, 53100 Siena, Italy

e-mail: porcelli@unisi.it

F. Ferretti

Department of Human Pathology and Oncology,

University of Siena, Siena, Italy

C. Vindigni

Pathological Anatomy,

Siena University Hospital, Siena, Italy

C. Scapellato

Clinical Pathology Laboratory,

Siena University Hospital, Siena, Italy 